\title{
Transatlantica
}

Revue d'études américaines. American Studies Journal

\section{Madame Kara Walker, notre artiste}

«Mon Ennemi, Mon Frère, Mon Bourreau, Mon Amour ", at ARC/ Musée d'art moderne de la ville de Paris

\section{Riché Deianne Richardson}

\section{OpenEdition}

12 Journals

\section{Édition électronique}

URL : http://journals.openedition.org/transatlantica/1872

DOI : $10.4000 /$ transatlantica. 1872

ISSN : $1765-2766$

Éditeur

AFEA

\section{Référence électronique}

Riché Deianne Richardson, « Madame Kara Walker, notre artiste», Transatlantica [En ligne], 2 | 2007, mis en ligne le 21 janvier 2008, consulté le 29 avril 2021. URL : http://journals.openedition.org/ transatlantica/1872 ; DOI : https://doi.org/10.4000/transatlantica.1872

Ce document a été généré automatiquement le 29 avril 2021

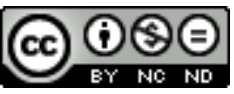

Transatlantica - Revue d'études américaines est mis à disposition selon les termes de la licence Creative Commons Attribution - Pas d'Utilisation Commerciale - Pas de Modification 4.0 International. 


\title{
Madame Kara Walker, notre artiste
}

«Mon Ennemi, Mon Frère, Mon Bourreau, Mon Amour », at ARC/ Musée

d'art moderne de la ville de Paris

\author{
Riché Deianne Richardson
}

1 «Mon Ennemi, Mon Frère, Mon Bourreau, Mon Amour, " the epic exhibition at ARC/ Musée d'art moderne de la ville de Paris running from 20 June to 9 September, reveals the creative genius and vision of the artist Kara Walker, who was born in Stockton, California in 1969. The show is her most comprehensive one yet in Europe and includes the form that Walker has uniquely developed and for which she is best known, cut-out black silhouettes that are sometimes small and at other times gigantic and room-size. But the beauty of the show lies in the fact that it is so multi-layered beyond these foundations. Among Walker's various other media are installations, cut paper images projected on the wall, room after room of works on paper, and two short films. Her works on paper singly-and sometimes in varying combinations-use materials such as watercolors, charcoal, colored pencil, ink, gouache, tempera, and colored crayon. This is a one-woman show of an artist who is clearly her own woman with a highly developed artistic vision and an already important and undeniable artistic legacy.

2 The silhouette, a cut-out, drawn or inked portrait against a light background to create the effect of a shadow, grew in popularity in Europe in the late $18^{\text {th }}$ and early $19^{\text {th }}$ centuries. The form recalls profiles on ancient Egyptian tomb walls. The term itself derives from Etienne de Silhouette, minister of finance for Louis XV who became unpopular for being financially conservative and who made paper cut-out portraits as a hobby. Silhouette art gained popularity in England during the Victorian era in part through French profilist Auguste Amant Constant Fidèle Edouart, who helped to circulate the term in England when the concept of the "shade" was more popular. The silhouette was particularly appealing before the daguerreotype and other forms of photography emerged. ${ }^{1}$

3 As one walks through this extensive exhibition's display rooms and takes it in, one encounters various themes, including those related to Africa, slavery in the antebellum South, the Civil War, figures like the eponymous Josephine Baker and even the contemporary entertainer Beyoncé. One might say, in fact, that the exhibition offers 
different lessons depending on who you are and how you look at it, even as it forces you to step outside of yourself and think about others in the past and present. A general aspect of Walker's work is that it highlights the bodies of different races and ages, sometimes in grotesque and unthinkable situations, but yet in forms that on the surface, always remain formal and elegant. Her wall projections and three-dimensional cutouts of trees that one walks through draw one's body into the complex narrative world of her art, reminding us that as individuals, we are a part of the rich and provocative historical tapestries that she weaves.

The exhibition tackles history and memories that some of us would rather not think about, or forget; it dares to portray what Nobel Laureate Toni Morrison, in writing, calls the " unspeakable ». ${ }^{2}$ This includes rape and mutilation, and other power relations and their consequences. Black figures against white walls, white figures in black paper, white on black violence, black on black violence, black babies with white fathers, black babies with white mothers, made from lust, love, hate, obligation. Never before was black and white so visually separate yet intricately multifaceted. Walker's uses of the classic silhouette form that has sometimes thematically highlighted themes of family and romance to portray the contrary relationships and atrocities associated with the institution of slavery makes her approach subversive and extremely ironic. Furthermore, through her style, Walker reveals the inherent irony in the popularity of the black silhouette among Europeans to portray the human form during the Enlightenment, a period when black bodies were dehumanized and associated with inferiority. Even after seeing the exhibition, it is hard to grasp and appreciate all that it has offered. One walks away enriched by a unique and transforming experience.

Paris is a city with an unparalleled beauty and artistic heritage. It hones the eye from childhood to appreciate a varying, progressing and yet intricately interlocking sense of proportion and scale. It seems to be the ideal place-and muse-for the orchestration and synthesis of the diverse features of the Walker exhibition, from the short animated films that evoke shadow theater and marionettes to the monumental silhouettes. This is the perfect exhibition for a Paris audience. As I sat downstairs in the museum after a seemingly endless afternoon, I felt exhilarated, inspired, renewed, and indeed, privileged to have seen the show in the kind of city where it so much seemed to belong.

In the contemporary era, Walker brings artistic gifts to Paris in the tradition of her many African Americans predecessors, such as Josephine Baker, Langston Hughes, James Baldwin, and Richard Wright, who, like Simone de Beauvoir, commemorates a 100th birthday in 2008. Like Michael Ray Charles, Walker has often included images in her work that are regarded as stereotypes of blacks, many of which remain very controversial. She has been accused of perpetuating stereotypes and her work was the centerpiece of a famous symposium at Harvard University. The symposium, which accompanied an exhibition of her work at Harvard's art center, was held on March 18-19, 1998 and sponsored by the W.E.B. DuBois Institute for Afro-American Research and the Carpenter Center for the Visual Arts. The event was moderated by Henry Louis Gates, Jr., and featured speakers such as Julian Bond, Kenneth Goings, Thelma Golden, and Betye Saar. It addressed questions related to the value of stereotypes in contemporary art, along with black collectibles. To be sure, that some of these latter objects, even with their tremendous historical weight as "contemptible » objects in American material culture, are valued to this day and thought to be beautiful, and even inspire a love-hate relationship among their most ardent collectors that include blacks 
from Julian Bond to Anita Pointer of the famed singing group The Pointer Sisters, are factors that well suggest the complex and even contradictory relationship that one might conceivably have to the work of an artist such as Walker. ${ }^{3}$ For her art can call up so many ambivalent feelings and a plethora of affective responses as it is viewed, from amazement and admiration to profound discomfort, shock and disbelief.

In just the past year, several controversies in the United States have suggested how much blacks continue to be stereotyped in some instances. They include talk show host Don Imus' reference to Rutgers women's basketball team members as «nappy-headed hos », comedian Michael Richards' outburst with the « N word » toward a black heckler at the Laugh Factory in Los Angeles, and Senator Joseph Biden's description of Illinois Senator and presidential candidate Barack Obama as «the first mainstream African American who is articulate and bright and clean». The Imus incident has led to widespread dialogues about the problem of black women's representation in hip-hop as «bitches » and « hos », and what if any limits there should be in how rap artists express themselves, especially if their lyrics include offensive or violent language. Such conversations can also be useful for thinking about questions concerning artistic freedom for visual artists such as Walker whose graphic images have inspired controversy. They mirror and extend longstanding debates that have existed in art and literary history about how African Americans should be represented. For instance, black artists have sometimes been pressured to approach black representations by emphasizing the "positive " and avoiding the "negative ", including stereotypes. The visual clues on which we must rely to discern who is who in Walker's uniformly black silhouette tapestries remind us that all of us have the potential to make presumptions on the basis of race or to perpetuate racial stereotypes.

Walker's repertoire began to crystallize and gain popularity at a time in the 1990s when many presumed that the most egregious historical African American caricatures and stereotypes had disappeared in American material culture and the media, and the status of African American artists seemed more precarious in the kinds of mainstream institutions that welcomed her. And yet, her work forces us to consider how this past established foundations for and continues to shape the world in which we now live. We should recognize Walker as a beacon for a generation of younger artists born after the civil rights era, grappling courageously and sometimes provocatively with the world inherited from it by drawing on history, here the antebellum era in the U.S. South. Walker's institutional recognition is exceptional in today's modern art scene, where the aesthetically innovative and quizzical rarely carry such forceful political overtone.

By featuring such imagery as southern plantations on an international stage in Europe in the contemporary era and using it as a backdrop for a range of cultural and social dynamics, her work reminds us that the slave trade itself was a multi-layered enterprise of national and global proportions with continuing significance. Her work provides a concrete illustration of how dynamics that are rooted in the U.S. South undergo processes of nationalization. ${ }^{4}$ It concretely illustrates how the region serves as a gateway for the globalization of culture in our time. ${ }^{5}$ Her work also helps to pose a challenge to American studies to focus more saliently on the South when analyzing the United States. For sometimes in dialogues in this field, the region becomes the elephant in the room that is ignored or dismissed altogether. Furthermore, at a time when there continues to be reluctance to dialogue about race in the United States, including the history of slavery, Walker's ability to bring some people to voice on such matters 
should not be taken lightly. In general, her work can also be drawn on as a valuable teaching tool. It is useful in the classroom, for instance, for extending the dialogue on slave narratives featuring the sexual abuse of black women such as Harriet Jacobs's Incidents in the Life of a Slave Girl as I sometimes do in teaching my African American literature survey for undergraduates.

The exhibition begins downstairs with « Endless Conundrum, An African Anonymous Adventuress » (2001), which draws its inspiration from modernist work by Matisse and Brancusi. Its feminine silhouette shape in a brown banana skirt at the top center in relief against a cream background draws the eye and evokes Josephine Baker. Other elements of the piece, such as hammers, a ball and chain, spikes, and nails evoke the traumas of slavery. There are also allusions to interracial rape, even as an African sculptural element featuring a couple recalls romance. The well-known piece by Walker entitled «Cut» (1998) which highlights an image of a girl with long braids with slashed wrists from which blood shoots out, and a blade in her left hand, is the most prominent piece we first encounter as the exhibition continues upstairs. It is a piece that implies self-mutilation. The girl is suspended in midair, and whether she is jumping, falling, clicking her heels together in ironic glee, or none of the above, is open to question. "Gone, An Historical Romance of a Civil War as It Occurred Between the Dusky Thighs of One Young Negress and Her Heart » (1994), which makes titular allusions to southern epics such as Gone with the Wind and The Clansman, incorporates standard Walker motifs such as the soldier, the southern belle, house servants, slave masters and children. It highlights how the veneer of gentility in the antebellum era masked the brutality of the slave system and reveals children as its youngest and most vulnerable victims. A piece made of cut paper and projected on the wall like « Darkytown Rebellion » (2001) evokes the soft colors and Cubist-like shapes in the murals of the Harlem Renaissance artist Aaron Douglas.

11 In a smaller series of pieces on canvas, including "Dinah's Dais" (1995) and "The Ship » (1995), Walker's artistry sends us to the opposite end of the spectrum in scale. All of these pieces are black silhouettes against a backdrop with just some cream showing through. In some instances, these smaller pieces throw the kinds of silhouette images by Walker into relief that we are accustomed to seeing depicted on a much larger scale, underscoring the level of detail, intricacy and precision in her work that might be easily overlooked when scrutinizing the larger pieces. One substantial series, «Do You Like Creme in Your Coffee and Chocolate in Your Milk?» (1997), includes sixty-six watercolor, colored pencil and graphite works on paper. It addresses cultural imperatives to avoid unflattering images in African American representations. It reveals a very ironic fantasy of famed white supremacist David Duke being raped by a black woman. This image reverses the historical instances in which black female bodies were dominated and violated by white men and appropriates white patriarchal power for black women. It boldly recognizes the sexuality, masculinity and potential desirability of a man whose blond iconicity is more frequently associated with his reactionary racial attitudes. Furthermore, it confronts historical southern taboos against interracial sex. In other places, the series invokes stereotypes of blackness such as animal sexuality. Throughout this series, many such works with deep and powerful messages are presented on notebook paper, a very casual veneer for Walker's complex and shocking themes. That this is the very kind of paper typically used by school 
students suggests Walker herself to be a consummate student of history and race relations.

One of the most exciting dimensions of this exhibition is Walker's two short black and white films, 8 Possible Beginnings or: The Creation of African-America (2005) and Testimony: Narrative of a Negress Burdened by Good intentions (2004). The former is interesting in part, for instance, for how it depicts a black male giving birth. This is a motif also evident in « The End of Uncle Tom »(1995), a large silhouette that features a figure in one scenario implied to be Uncle Tom who is connected by an umbilical cord to a baby on the ground. Such images challenge the intimate and sometimes pathological association of the black female body with the maternal while extending the theme of male rape invoked in other pieces such as the aforementioned one mentioning David Duke. They also parallel the theme of lynching treated elsewhere in this film.

In her films, Walker adapts her silhouette art forms and puts them into motion, taking her artistry into a new dimension for her audience. The films foreground silhouettes, giving further depth to Walker's characters or bringing to life and putting into action processes that her still images waxed onto the wall have often shown, from the labor of birth to acts of sex. Indeed, her films give new meaning to the concept of motion pictures. That these are fundamentally silent films means that we focus all the more on the visual. That the films reveal Walker orchestrating, in some instances, literally pulling the strings attached to her silhouettes, points to how much she controls what her art says, and to her potential to even push the buttons of her audience.

Opinions about her may differ and indeed, a lot. Walker is the kind of artist about whom many people seem to have an opinion. A lot of noise, for better and for worse, has sometimes surrounded her profound and provocative creation. ${ }^{6}$ Pieces in the series " Do You Like Creme in Your Coffee and Chocolate in Your Milk? "(1997) have been developed as a response to some of her critics. She seems to caution against focusing on the provocative aspect of her art to the point of overlooking its other qualities. One of the small watercolors possibly relates her critics to a « ship of fools » while also making an allusion to the larger traumatic history of the Middle Passage. Other pieces suggest the dangers of becoming too obsessive with refuting black stereotypes. Walker's seemingly meteoric rise in the art establishment, including a «MacArthur Genius Grant » at the ripe young age of 28 (she was, in fact, the youngest recipient ever), inspired some controversy. Most notably, Betye Saar, a famed veteran artist who is herself noted for featuring images of Aunt Jemima in her early art, began an extensive letter-writing campaign in the wake of Walker's award and has been one of her most vocal critics. Saar even referred to Walker as "young and foolish». In a sense in keeping with the visual qualities of her fundamental silhouette form, and in spite of her success, Walker has often been shadowed in her career by a range of questions that were either spoken outright or whispered just beneath the surface. How could a neophyte like her on the art scene have garnered such critical acclaim so quickly? How could someone so young have risen so quickly in the art establishmen? Who is she, or even, more bitterly, who does she think she is ? Why does she do what she does anyway and what on earth does it mean! How and why did she get the MacArthur? Yet, a walk through an encompassing exhibition like this one reveals Walker's very genius. This vast exhibition's multi-faceted and yet highly integrated conceptual contours show Walker as a hard and diligent worker at what she does, that she is a rigorous thinker 
with an incredibly dynamic vision as an artist, and the inexhaustible depths of her originality. She is not the new kid on the block anymore, if she ever was. She is in a league of her own. She is truly, whatever her critics have ever said about her, all grown up.

This show of Walker's work is important to see in part because it is unprecedented in its comprehensiveness. It gives us an opportunity to examine Walker's artistic repertoire, and to see its staggering range, in all of its splendor-and utter rawness. Walker's exhibition is probably not for anyone who wants to spend a leisurely hour at the museum. It offers an overwhelming number of images that must be given some time and examined closely to recognize their deeper meaning and significance. An illustrated catalogue by Philippe Vergne and others entitled Kara Walker: My Complement, My Enemy, My Oppressor, My Love, which includes critical essays related to Walker's work, accompanies the exhibition. ${ }^{7}$ Other treats that accompany the exhibition, and that lend distinction and significance to its presence in Paris and at ARC/Musée d'art moderne de la ville de Paris, include a beautifully illustrated bulletin in newspaper form almost entirely in French. Among a range of rich components, it features a dialogue between Toni Morrison and Edouard Glissant. Walker's exhibition premiered at the Walker Art Center in Minneapolis, Minnesota in February 2007. It will continue on to the Whitney Museum of American Art in New York, New York (October 11-February 3). It concludes at the Hammer Museum in Los Angeles, California (March 2-June 8 2008).

Calendar of the exhibition.

Companion to the exhibition.

\section{NOTES}

1. For more on the history of silhouettes, see, for instance, Penley Knipe, « Shades and Shadow-Pictures: The Materials and Techniques of American Portrait Silhouettes, » a paper delivered at the Book and Paper specialty group session, American Institute for Conservation $27^{\text {th }}$ Annual Meeting, June 8-13, 1999 in St. Louis, Missouri.

2. For instance, Gwendolyn DuBois Shaw provides an in-depth treatment of the topic of the unspeakable in Walker's work in Seeing the Unspeakable : The Art of Kara Walker (Durham : Duke University Press, 2004).

3. Patricia A. Turner uses the term « contemptible collectibles » to refer to the « insidious » images of blacks in Ceramic Uncles and Celluloid Mammies : Black Images and Their Influence on Culture (New York : Anchor Books, 1994). For more on black collectibles, see Kenneth W. Goings, Mammy and Uncle Mose : Black Collectibles and American Stereotyping (Bloomington : Indiana University Press, 1994).

4. I have discussed such dynamics related to the region in some of my own work. See, for instance, Riché Richardson, Black Masculinity and the U.S. South : From Uncle Tom to Gangsta (Athens : The University of Georgia Press, 2007). 
5. See Patricia Yaeger, « Circum-Atlantic Superabundance : Milk as World-Making in Alice Randall and Kara Walker, » in the special issue entitled « Global Contexts, Local Literature : The New Southern Studies, » ed. Kathryn McKee and Annette Trefzer, American Literature 78 (December 2006) : 769-98.

6. The International Review of African American Art, edited by Juliet Bowles, provided one of the earliest treatments of the controversy surrounding Walker's work in an issue entitled "Stereotypes Subverted ? Or For Sale : Extreme Times Call for Extreme Heroes, "14:3 (1997), which also continued in a later issue in a section entitled «Stereotypes Subverted ». See the International Review of African American Art, 15:2 (1998).

7. See Kara Walker : My Complement, My Enemy, My Oppressor, My Love, Philippe Vergne, Sander Gilman, Thomas McEvilley, Robert Storr, and Kevin Young (Minneapolis, Minnesota : Walker Art Center, 2007).

INDEX

Thèmes : Trans'Arts

\section{AUTEUR}

RICHÉ DEIANNE RICHARDSON

UC Davis, California 